\title{
New Disease Reports \\ First report of Fusarium wilt of eggplant caused by Fusarium oxysporum f. sp. melongenae in Iran
}

\author{
Negin Safikhani ${ }^{1} *$, Bahar Morid ${ }^{2}$ and Hamid Reza Zamanizadeh $^{1}$ \\ ${ }^{1}$ Department of Plant Pathology, Agriculture and Natural Resources, Science and Research Branch, Islamic Azad \\ University, Tehran, Iran; ${ }^{2}$ Department of Plant Protection, College of Agriculture, Takestan Branch, Islamic Azad University, \\ Takestan, Iran \\ *E-mail: negin_Safikhani@yahoo.com
}

Received: 05 Sep 2013. Published: 19 Nov 2013. Keywords: Solanum melongena, fungal plant disease

In 2012, eggplant (Solanum melongena) production in several greenhouses and fields was surveyed in Iran. In Hormozgan and Semnan provinces, 15 and $12 \%$ of fields surveyed, respectively, were infected with an unknown disease. Those affected plants exhibited leaf chlorosis and slight vein clearing on the outer leaflets, slight yellowing of foliage and wilting of upper leaves and eventual death of the plant. Necrotic tissue fragments from discoloured vascular stem tissue were surface sterilised by soaking in $10 \%$ bleach solution for five minutes and plated on potato dextrose agar (PDA). Single-spore isolates were obtained and transferred to PDA and carnation leaf agar (CLA) to investigate culture characteristics and morphology (Nelson et al., 1983). Twenty-six isolates were identified as Fusarium., including 12 isolates that were initially identified as Fusarium oxysporum due to production of characteristic three to five septate, sickle-shaped macroconidia with a foot-shaped basal cell, on branched conidiophores or on the surface of sporodochia. Three septate spores were more common. Microconidia were borne on simple phialides arising laterally and were abundant, oval-ellipsoid, straight to curved and non-septate in culture. A typical cream to pink colony developed, often with purple tinge, on PDA (Nelson et al., 1983). After PCR amplification of genomic DNA using the specific primer PF02-3 (Baysal et al., 2010), morphological identity was confirmed as Fusarium oxysporum f. sp. melongenae by the presence of a specific, characteristic band visible at around $70 \mathrm{bp}$. The other isolates were identified as $F$. solani.

Pathogenicity tests were performed twice for each of 12 isolates using a root-dip inoculation method (Baysal et al., 2010). Wounded roots ofnine $S$. melongena (cv. 'Pala') seedlings at the six-leaf stage were submerged for $15 \mathrm{~min}$ in a conidial suspension $\left(1 \times 10^{6}\right.$ conidia/ml in sterile water), while control plants were dipped in sterile tap water. Seedlings were transplanted into pots and maintained in a growth chamber. After 3-4 weeks, severity of wilt symptoms was assessed using a wilt index ranging from 0 (no symptoms) to 4 (plant death) (Morid et al., 2012). All 12 isolates tested were pathogenic to eggplant with a wilt index ranging from 1.2 to 3.4 (average $=2.8$ ). Symptoms observed on inoculated plants were similar to those in commercial greenhouses, including leaf chlorosis and necrosis and eventual death. Control plants showed no symptoms, and two other members of the Solanaceae (tomato and pepper) tested with the same method displayed no symptoms. Fusarium oxysporum f. sp. melongenae was successfully re-isolated from the stems of disease-affected inoculated plants, thereby completing Koch's postulates. Fusarium oxysporum f. sp. melongenae is a major soil-borne pathogen and one of the causal agents of vascular wilt disease in eggplant. Occurrence of $F$. oxysporum on S. melongena has been reported in Japan, Korea, China, Italy, Greece, Spain, Turkey, the USSR, USA-Florida and Fiji (Yildiz et al., 2012). This is the first report of $F$. oxysporum f. sp. melongenae in Iran. Previously, the causal agent of Fusarium wilt of eggplant in Iran was attributed solely to F. solani (Gerlach \& Ershad, 1970).

\section{References}

Baysal Ö, Siragusa M, Gümrükcu E, Zengin S, Carimi F, Sajeva M, Teixeira da Silva JA, 2010. Molecular characterization of Fusarium oxysporum f. sp. melongenae by ISSR and RAPD markers on eggplant. Biochemical Genetics 48, 524-537

[http://dx.doi.org/10.1007/s10528-010-9336-1]

Gerlach W, Ershad D, 1970. Beitrag zur kenntnis der Fusarium - und Cylindrocarpon-arten in Iran. Nova Hedwigia 20, 725-784

Morid B, Hajmansoor S, Kakvan N, 2012. Screening of resistance genes to Fusarium root rot and Fusarium wilt diseases in tomato (Lycopersicon esculentum) cultivars using RAPD and CAPs markers. European Journal of Experimental Biology 2, 931-939.

Nelson PE, Toussoun TA, Marasas WFO, eds, 1983. Fusarium Species: An illustrated manual for identification. Pennsylvania, USA: Penn State University Press.

Yildiz HN, Handan Altinok H, Dikilitas M, 2012. Screening of rhizobacteria against Fusarium oxysporum f. sp. melongenae, the causal agent of wilt disease of eggplant. African Journal of Microbiology Research 6, 3700-3706.

To cite this report: Safikhani N, Morid B, Reza Zamanizadeh H, 2013. First report of Fusarium wilt of eggplant caused by Fusarium oxysporum f. sp. melongenae in Iran. New Disease Reports 28, 16. [http://dx.doi.org/10.5197/j.2044-0588.2013.028.016] 